Research Article

\title{
Research on the Seismic Performance of Straw Panel-Infilled Concrete Frame by Shaking Table Test
}

\author{
Jia Zhu $\mathbb{D}^{1,2}$ Yuling Bian ${ }^{10},^{3}$ and Aiping Zhou ${ }^{1}{ }^{1}$ \\ ${ }^{1}$ National Engineering Research Center of Biomaterials, Nanjing Forestry University, Nanjing 210037, China \\ ${ }^{2}$ School of Architecture and Transportation Engineering, Guilin University of Electronic Technology, Guilin 541004, China \\ ${ }^{3}$ Wuxi Vocational Institute of Commerce, 809 Qianhu Rd., Wuxi 214153, China
}

Correspondence should be addressed to Yuling Bian; bianyuling@wxic.edu.cn

Received 23 December 2020; Revised 21 February 2021; Accepted 24 April 2021; Published 5 May 2021

Academic Editor: Jian Ji

Copyright ( 92021 Jia Zhu et al. This is an open access article distributed under the Creative Commons Attribution License, which permits unrestricted use, distribution, and reproduction in any medium, provided the original work is properly cited.

\begin{abstract}
Infill wall-frame interaction-induced damage and failure have been found in many previous earthquakes due to the inappropriate estimation of the stiffness of infill walls. It is a common knowledge of design philosophy that properly lowering the lateral stiffness of infill wall may significantly improve the seismic performances of concrete frames. Fabricated straw wall, a sandwich-type structure with tenon and groove, is proposed as a new type of lightweight and environment-friendly infill wall. The lateral stiffness is much lower than that of masonry infill wall. Shaking table tests were carried out for a concrete frame structure with fabricated straw wall, as well as for a frame with masonry infill wall for comparison. Results show that failure modes of them are different. Plastic hinges took place at the ends of beams in the frame with fabricated straw infill wall, different from the frame with masonry infill wall where the plastic hinges emerged at the ends of columns. Numerical analysis was conducted to verify and illustrate the failure mechanism. It indicates that the straw panel-infilled concrete frame well matches the design philosophy and presents better seismic performance.
\end{abstract}

\section{Introduction}

Masonry infill wall used as partial wall of reinforced concrete frame structures is usually treated as the nonstructural component in design philosophy. However, masonry infill wall exerts a significant effect on the stiffness of frame structures [1-4] and the structural dynamic performances [5]. Design codes $[6,7]$ take a natural vibration period reduction factor to account for the stiffness contribution of the masonry infill walls; e.g., the factor is specified as $0.6-0.9$ by the Chinese code [7].

The current design philosophy poses serious problems, as it did in the case of Wenchuan earthquake. On May 12, 2008, an Ms8.0 earthquake struck Wenchuan area where masonry infill wall is extensively adopted. A 3-story building of frame structure in Beichuan is shown in Figure 1 [8]. To set street shops for the building, few infill walls were set on the ground floor, while many infill walls were arranged on other floors, making the ground floor much weaker than other layers. Finally, all the bottom columns broke at ends, and the whole building inclined dramatically. The same type of failure is presented in Figure 2 [9]. It is a damaged column of a 6-story building in Dujiangyan city. Its ground floor acted as a garage with no walls. Infill walls on the upper floors made the stiffness vary greatly between the first and second story, so the damage of bottom columns occurred.

Witnessing all these damages and failure induced by the interaction between the masonry infill wall and concrete frame $[2,4,9]$, the significant role of masonry infill walls in frame structures is gradually realized. Related experiments [10-12] and numerical analyses [13-15] are conducted by different scholars. Some codes $[16,17]$ recommend struts to represent masonry infill walls in calculations. However, due to the scattered data offered by different experiments, along with the difficulty in modeling brittle materials [18], a widely accepted method to precisely consider the masonry stiffness is still absent.

To eliminate the great disparity in lateral stiffness between stories generated by masonry infill walls, arranging 


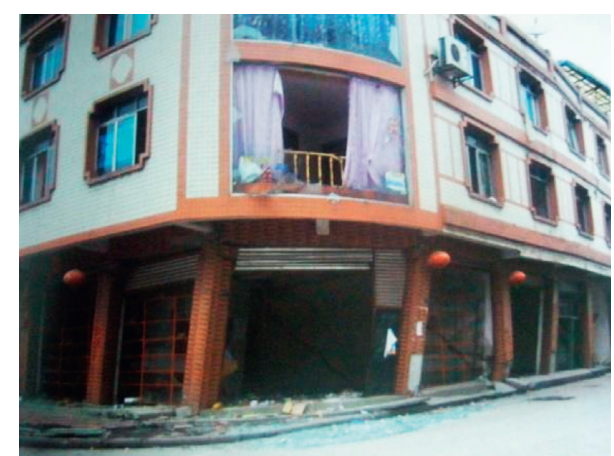

FIgURE 1: Damage of a 3-story frame structure [8].

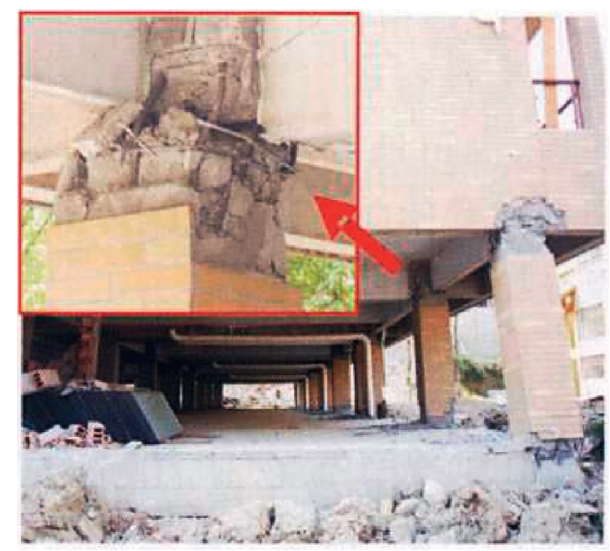

FIgURE 2: Damage of the bottom columns of a 6-story building [9].

masonry infill walls equivalently on each story is a simple way. However, this method is generally not practical, since the main entrances, garage, or stores are often set on the first floor. Due to the need for rational use of space, the layout of masonry infill walls on first floor is quite limited. An effective approach is to lower the stiffness of the masonry infill wall directly. Either decreasing their total number or replacing the masonry with other proper materials would work. By proposing a sandwich-type of fabricated straw panel, the latter method is chosen and studied.

\section{Fabricated Straw Brick}

To properly replace the masonry bricks, a sandwich-type of fabricated straw panel is advanced. With a low elastic modulus [19], straw panels own much lower stiffness compared with masonry bricks [20]. Due to the flexible tenon connection between straw panel and frame, a certain deformation is allowed under horizontal loads and actions. Thus, the interaction between the straw panel infill wall and concrete frame is weak. It also shares the characteristics of sound insulation and self-heat insulation [21-24]. Meanwhile, the straw panels are remarkably fire-resistant considering the compactness [25].

The proposed straw panel is a sandwich structure with tenon and groove, consisting of a low-density straw board $\left(\rho \leq 400 \mathrm{~kg} / \mathrm{m}^{3}\right)$ and 2 high-density straw boards $(\rho \geq 700 \mathrm{~kg} /$ $\mathrm{m}^{3}$ ). The low-density board with good thermal insulation and sound insulation performance is used as the lining, of which 2 high-density boards are placed on both sides. The lower end of the low-density lining board is a groove. The high-density outer panel and the low-density lining board are staggered to form a tenon and groove. Considering the requirements of the building modulus and the conditions in the transportation and construction process, the size of the straw panel is decided as shown in Figure 3.

Shaking table tests were carried out for a straw panelinfilled frame, as well as for a masonry infilled frame for comparison, to study their seismic performance.

\section{Experimental Investigation}

\subsection{Experimental Design}

3.1.1. Similitude of the Model. Scale models are used in the shaking table tests, which are representative of the prototype structure according to a certain similar relationship. The designed similitude of model is presented in Table 1.

3.1.2. Experimental Model Design. The test models of the frame structures are $1 / 3$ scale models of the prototype structure. Two identical reinforced concrete frames are designed for comparison. Each frame is a 1-bay, 3-story structure, filled with masonry bricks or straw panels, respectively. All frame beams, columns, and floor (roof) panels are cast-in-place.

In order to ensure the consistency of these 2 concrete frames, synchronous construction and simultaneous pouring are adopted, and each layer of steel and concrete is obtained from the same batch of materials. (For the convenience of description in this article, the frame with masonry bricks is called brick frame, and the frame with straw panels is called straw frame.) The geometrical sizes of models are presented in Tables 2 and 3 .

According to the Chinese Code for Design of Concrete Structures [26], the component layout and the reinforcement diagrams of components in the test structures are designed and shown in Figures 4-6. The straw brick is presented in Figures 3 and 7, and the photo of test structures is shown in Figure 8.

3.1.3. Construction and Installation of Infill Walls. As the brick frame is filled with masonry bricks, its infill wall was constructed in accordance with the requirements of the Chinese current code [27].

There are currently no relevant regulations or specifications as references for straw frame, so the installation plan was determined based on the principle of structural stability, the geometrical sizes of straw brick, and the suggestions of the manufacturer's technicians. Figure 9 illustrates the connections between straw components and frame; specific installation steps are as follows:

(1) While the straw bricks with tenon and groove are easy to connect with each other vertically, vertical long straw strips were needed to link the boards horizontally with air nails to enhance the integrity of 

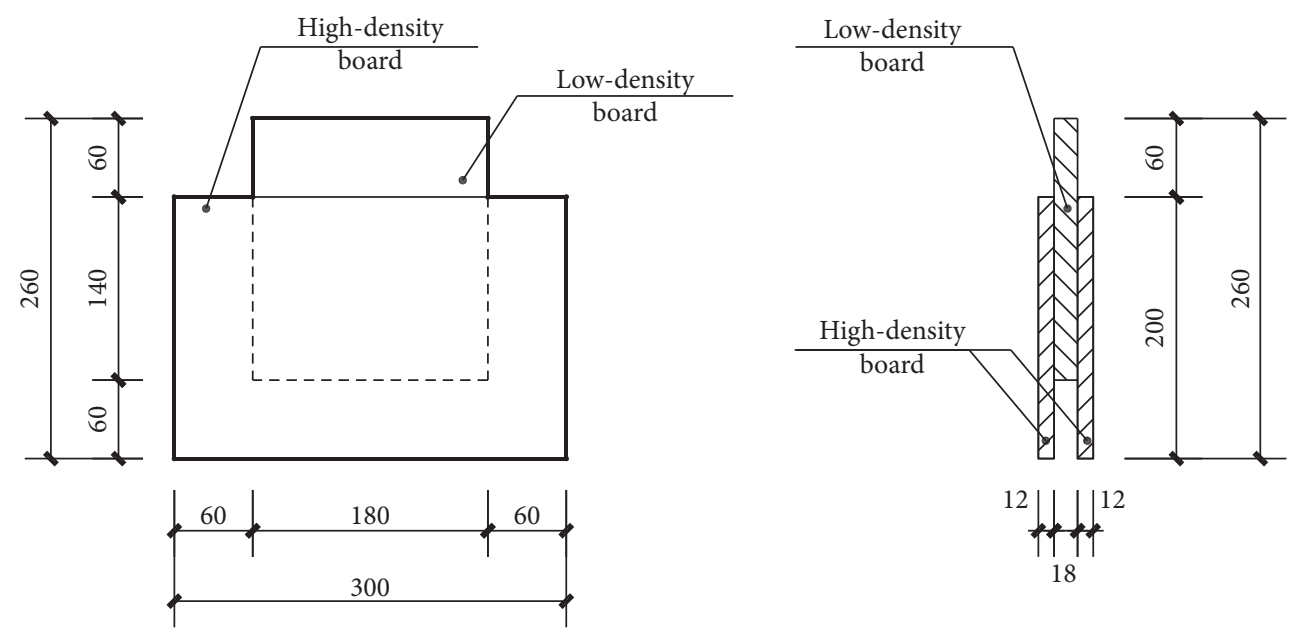

FIgURE 3: Geometrical sizes of a straw brick (unit: $\mathrm{mm}$ ).

TABle 1: Designed similitude of the model.

\begin{tabular}{|c|c|c|c|c|}
\hline Type & Physical properties & Dimension & Similitude & Similarity constant \\
\hline \multirow{3}{*}{ Material features } & Stress & $F L^{-2}$ & $S_{\sigma}=S_{E}$ & 1 \\
\hline & Modulus of elasticity & $F L^{-2}$ & $S_{E}$ & 1 \\
\hline & Mass density & $F T^{2} L^{-4}$ & $S_{\rho}=S_{E} / S_{l}$ & 3 \\
\hline \multirow[t]{2}{*}{ Geometrical features } & Length & $L$ & $S_{l}$ & $1 / 3$ \\
\hline & Mass & $F L^{-2} T^{2}$ & $S_{m}=S_{\rho} S_{l}^{3}$ & $1 / 9$ \\
\hline \multirow[t]{2}{*}{ Dynamic features } & Stiffness & $F L^{-1}$ & $S_{k}=S_{E} S_{l}$ & $1 / 3$ \\
\hline & Acceleration & $L T^{-2}$ & $S_{a}^{n}=S_{l} / S_{t}^{2}$ & 1 \\
\hline
\end{tabular}

TABle 2: Geometrical sizes of models (unit: m).

\begin{tabular}{lccc}
\hline Structure & Length & Width & Height \\
\hline Prototype structure & 4.5 & 4.5 & 9 \\
Test structures & 1.5 & 1.5 & 3 \\
\hline
\end{tabular}

TABLE 3: Geometrical sizes of components (unit: $\mathrm{mm}$ ).

\begin{tabular}{lccccc}
\hline \multirow{2}{*}{ Structure } & \multicolumn{2}{c}{ Column } & \multicolumn{2}{c}{ Beam } & \multirow{2}{*}{ Slab } \\
& $H_{\mathrm{c}}$ & $B_{\mathrm{c}}$ & $H_{\mathrm{b}}$ & $B_{\mathrm{b}}$ & \\
\hline Prototype structure & 300 & 300 & 300 & 150 & 120 \\
Test structures & 100 & 100 & 100 & 50 & 100 \\
\hline
\end{tabular}

the straw wall. The straw strips, with the basic geometric size of $120 \mathrm{~mm} \times 18 \mathrm{~mm} \times 900 \mathrm{~mm}$, could be perfectly stuck between two horizontally adjacent straw boards, as shown in Figure 9.

(2) Straw strips and frame beams are fixed by embedded parts to avoid slipping and falling off during the vibration. The 10-centimeter-long steel bars in Figure 9 acted as the embedded parts whose diameter is $12 \mathrm{~mm}$. Proper holes were reserved at the ends of the straw strips for the embedded parts.

(3) To prevent the straw wall from falling off or tilting out of the frame, steel plates were used to fix the straw wall to the frame. The steel plates were coated with glue to ensure the connection between the straw wall and frame.

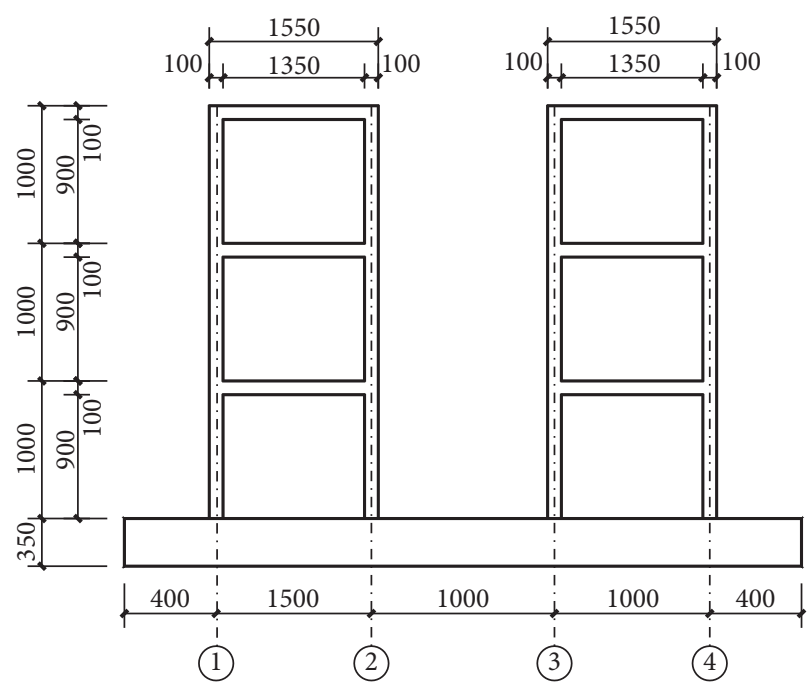

FIgURE 4: Front elevation view of test structures (unit: $\mathrm{mm}$ ).

(4) In order to guarantee the connections, all straw components were checked before installation, those of which with large deviation in geometrical sizes were screened out.

(5) The installation order from bottom to top and from right to left was followed to ensure that the first straw board at the floor level fits the floor correctly, and that straw boards fits well with the neighboring straw strips. 


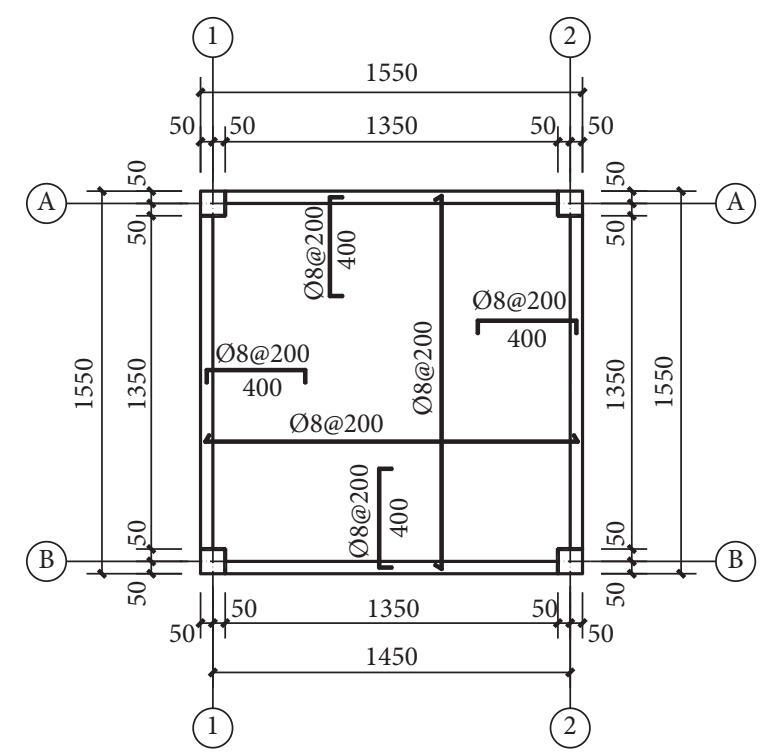

FIgURE 5: Reinforcement diagram of floor slab (unit: $\mathrm{mm}$ ).

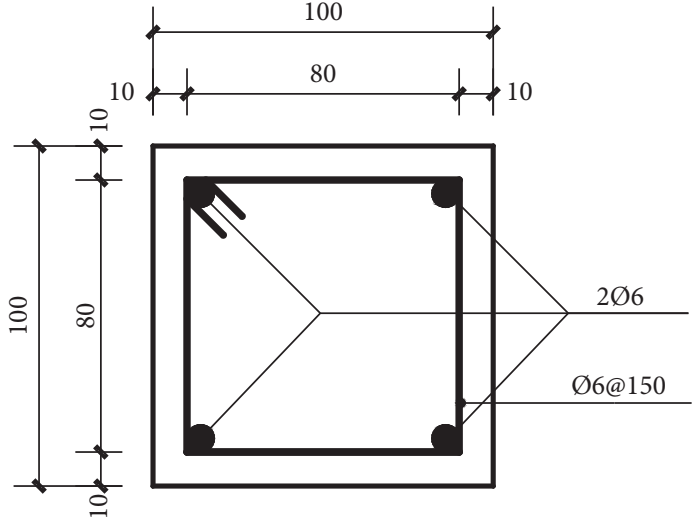

(a)

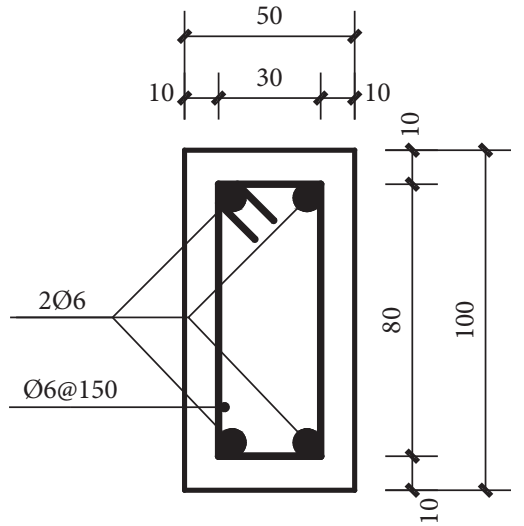

(b)

Figure 6: Reinforcement diagrams of columns and beams (unit: mm). (a) Column. (b) Beam.

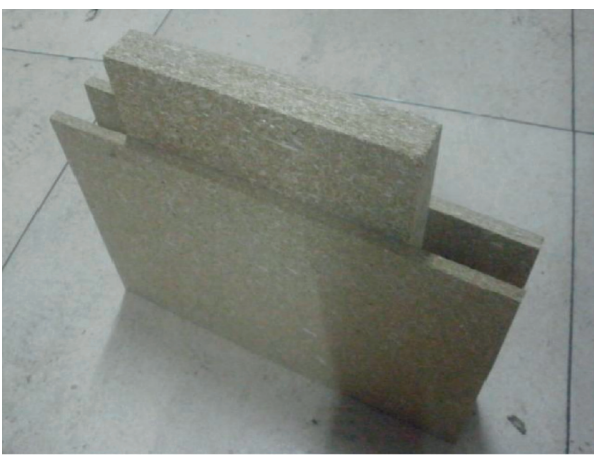

Figure 7: The straw brick.

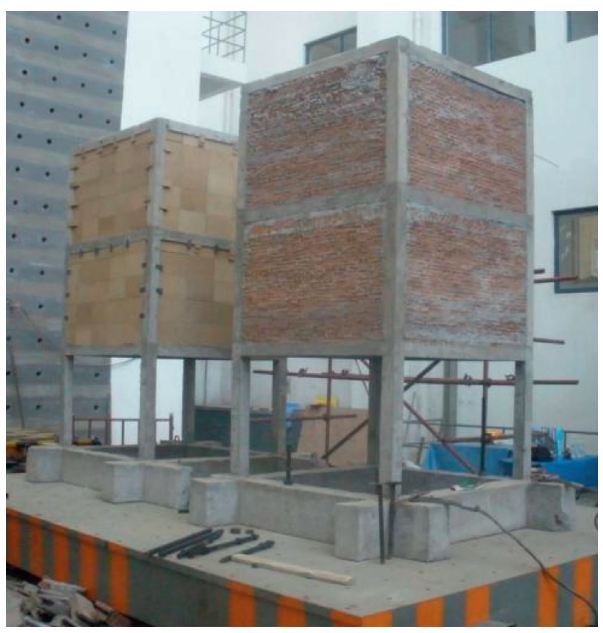

FIGURE 8: Test structures on shaking table. 


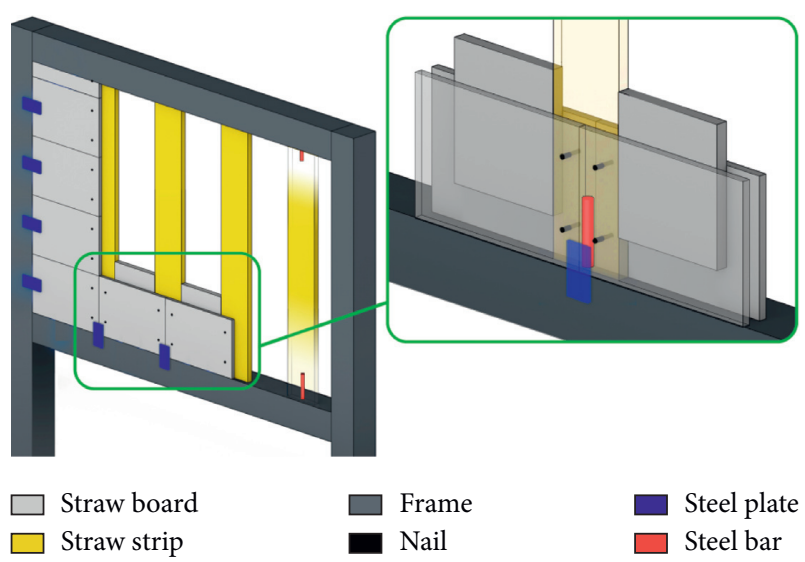

FIgURE 9: Connections between straw components and frame.

(6) By conducting the above steps, construction deviation accumulated on the last row of straw boards. Standard straw boards were cut on-site to ensure that the size of the last row and column meets the requirements.

(7) After all installations were complete, the straw strips and straw boards were connected with air nails. $20 \mathrm{~mm}$ air nails with an interval of $10 \mathrm{~cm}$ were adopted.

3.1.4. Experimental Materials. The parameters of experimental materials are shown in Table 4.

\subsection{Shaking Table Test}

3.2.1. Apparatus. This test was carried out on the earthquake simulation shaking table of the Civil Engineering Test Center in Southeast University. The vibration table is an assembled single-degree-of-freedom seismic simulation vibration table, which is mainly composed of a foundation, a table, a dynamic actuator, a controller, an oil source system, and a data acquisition and analysis system.

3.2.2. Spectrum Waves and Load Cases. According to the Chinese current code [7], 3 seismic waves were selected as the input waves in the experiment, namely, the EL Centro wave, the Taft wave, and an artificial wave. In the experiment, the seismic waves are firstly scaled with the acceleration peak value according to the working conditions. And the duration is compressed according to the similar coefficient, which is $23.2 \mathrm{~s}$ at last. All of them then work as the excitation input for the test.

During the test, the EL Centro wave, Taft wave, and the artificial wave were successively input in one way horizontally. White noise with a peak acceleration of $35 \mathrm{~cm} / \mathrm{s}^{2}$ was employed before and after each stage to test the dynamic characteristics of the structures. Ground motions were selected based on the Chinese current code [7] for research. The testing cases are presented in Table 5.

\subsubsection{Measuring Point Layout and Data Collection. After} the models had been installed, the measuring points were arranged. 7 magnetic accelerometers (numbered a1-a7) and
7 pull-wire displacement meters (numbered D1-D7) were employed during the tests. An acceleration sensor and a displacement meter were arranged on the (2) axis and (4) axis of each floor elevation, roof, and vibration table base of the models, as shown in Figure 10.

The AdCRAS dynamic data collection system developed by Nanjing Anzheng Software Company was adopted in the test. The system is able to collect the acceleration and displacement response of the model under various working conditions. The sensitivity of acceleration sensor and displacement meter is shown in Table 6.

\subsection{Test Results and Discussion}

3.3.1. Experimental Observations. In the case of gradually increasing the peak acceleration of seismic waves, the occurrence and specific development of cracks are explained as follows:

(1) Under the Peak Ground Acceleration (PGA) of $35 \mathrm{~cm} / \mathrm{s}^{2}$, the horizontal shaking of the models was inconspicuous. No visible cracks appeared on the models.

(2) Under the PGA of $70 \mathrm{~cm} / \mathrm{s}^{2}$, cracks appeared at the bottom of the brick frame beams, and tiny cracks took place at the top of the bottom columns.

(3) Under the PGA of $140 \mathrm{~cm} / \mathrm{s}^{2}$, previous cracks expanded with low amplitude, and a few horizontal cracks appeared at the top of the bottom column in the brick frame.

(4) Under the PGA of $220 \mathrm{~cm} / \mathrm{s}^{2}$, micro cracks on the top of the bottom column in the brick frame began to expand, and cracks appeared in all four columns with a maximum length of $6 \mathrm{~cm}$. Meanwhile, diagonal cracks took place in both ends of the 1st floor beams in the straw frame, as shown in Figure 11.

(5) Under the PGA of $400 \mathrm{~cm} / \mathrm{s}^{2}$, top cracks of bottom column in brick frame continued expanding, some of which expanded to the full section. Meanwhile, micro cracks appeared on top of the column in the second story. Cracks in the 1st floor beam of the straw frame expanded, especially in the beams along the shaking direction. During vibration, the gap between straw panels and beams caused by the deformation of the straw frame was observed.

(6) Under the PGA of $620 \mathrm{~cm} / \mathrm{s}^{2}$, cracks on the bottom column in the brick frame all extended to the full cross section; the maximum width of which is $2 \mathrm{~mm}$. Cracks in the beams of the 1st and 2nd floor of the straw frame grew, and those of the 1st floor even extended to the full cross section.

(7) Under the PGA of $800 \mathrm{~cm} / \mathrm{s}^{2}$, the width of the cracks on the bottom column in the brick frame increased to $3 \mathrm{~mm}$, and cracks appeared at the bottom of some columns. The maximum width of the crack at the beam ends in the straw frame is about $2 \mathrm{~mm}$. The gap between the straw panels and the columns at the top story was between $3 \mathrm{~cm}$ and $5 \mathrm{~cm}$. 
TABle 4: Parameters of experimental materials.

\begin{tabular}{|c|c|c|c|c|c|c|c|}
\hline \multirow{2}{*}{ Material } & \multirow{2}{*}{ Concrete } & \multirow{2}{*}{ Steel } & \multicolumn{2}{|c|}{ Masonry brick } & \multirow{2}{*}{ Mortar } & \multirow{2}{*}{$\begin{array}{c}\text { Straw brick } \\
\text { Density }\end{array}$} & \multirow{2}{*}{$\begin{array}{c}\text { Straw strip } \\
\text { Density }\end{array}$} \\
\hline & & & Elastic modulus (MPa) & Grade & & & \\
\hline Parameter & $\mathrm{C} 25$ & HPB235 & 2400 & MU10 & M5 & $559 \mathrm{~kg} / \mathrm{m}^{3}$ & $700 \mathrm{~kg} / \mathrm{m}^{3}$ \\
\hline
\end{tabular}

TABle 5: Testing cases.

\begin{tabular}{|c|c|c|c|c|c|c|c|c|c|}
\hline \multirow{2}{*}{ Stage } & \multirow{2}{*}{ Case no. } & \multirow{2}{*}{ Input wave } & \multicolumn{2}{|c|}{ Peak acceleration $\left(\mathrm{cm} / \mathrm{s}^{2}\right)$} & \multirow{2}{*}{ Stage } & \multirow{2}{*}{ Case no. } & \multirow{2}{*}{ Input wave } & \multicolumn{2}{|c|}{ Peak acceleration $\left(\mathrm{cm} / \mathrm{s}^{2}\right)$} \\
\hline & & & Target value & Measured value & & & & Target value & Measured value \\
\hline \multirow{4}{*}{1} & 1 & White noise & 35 & 48 & \multirow{4}{*}{5} & 17 & White noise & 35 & 42 \\
\hline & 2 & EL Centro & 35 & 28 & & 18 & EL Centro & 400 & 493 \\
\hline & 3 & Taft & 35 & 49 & & 19 & Taft & 400 & 405 \\
\hline & 4 & Artificial wave & 35 & 64 & & 20 & Artificial wave & 400 & 278 \\
\hline \multirow{4}{*}{2} & 5 & White noise & 35 & 40 & \multirow{4}{*}{6} & 21 & White noise & 35 & 47 \\
\hline & 6 & EL Centro & 70 & 92 & & 22 & EL Centro & 620 & 531 \\
\hline & 7 & Taft & 70 & 107 & & 23 & Taft & 620 & 539 \\
\hline & 8 & Artificial wave & 70 & 144 & & 24 & Artificial wave & 620 & 531 \\
\hline \multirow{4}{*}{3} & 9 & White noise & 35 & 45 & \multirow{8}{*}{7} & 25 & White noise & 35 & 39 \\
\hline & 10 & EL Centro & 140 & 214 & & 26 & EL Centro & 800 & 530 \\
\hline & 11 & Taft & 140 & 216 & & 27 & Taft & 800 & 562 \\
\hline & 12 & Artificial wave & 140 & 206 & & 28 & White noise & 35 & 59 \\
\hline \multirow{4}{*}{4} & 13 & White noise & 35 & 43 & & 29 & EL Centro & 1100 & 576 \\
\hline & 14 & EL Centro & 220 & 280 & & 30 & Taft & 1100 & 715 \\
\hline & 15 & Taft & 220 & 417 & & & & & \\
\hline & 16 & Artificial wave & 220 & 348 & & & & & \\
\hline
\end{tabular}

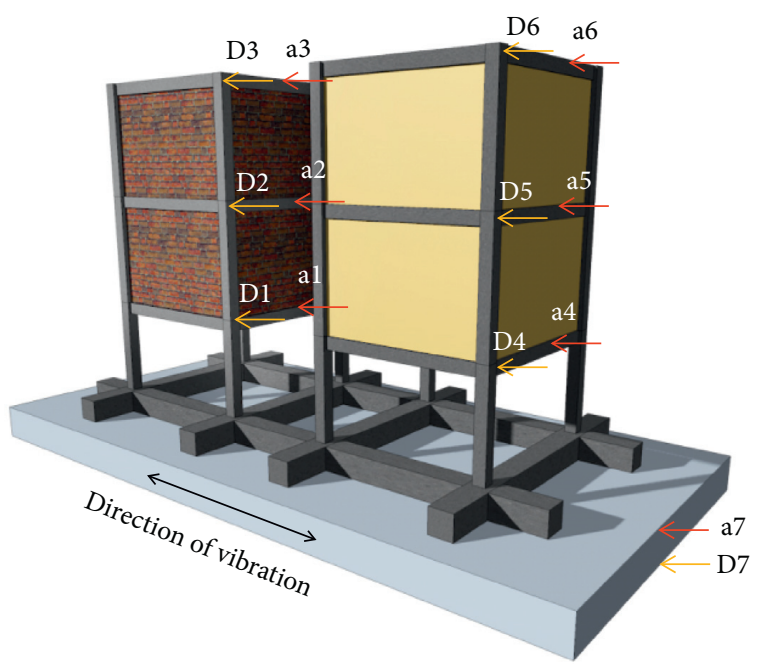

FIGURE 10: Layout of measuring point.

TABLE 6: Sensitivity and measuring range of sensors.

\begin{tabular}{lcccc}
\hline \multicolumn{2}{c}{ Accelerometer } & \multicolumn{2}{c}{ Displacement meter } \\
Measuring point & Sensitivity $\left(\mathrm{mV} / \mathrm{m} \cdot \mathrm{s}^{2}\right)$ & Measuring point & Sensitivity $(\mathrm{V} / \mathrm{m})$ & Measuring range $(\mathrm{mm})$ \\
\hline a1 & 10.02 & D1 & 6.21 & 750 \\
a2 & 9.92 & D2 & 6.15 & 750 \\
a3 & 9.90 & D3 & 6.13 & 750 \\
a4 & 10.16 & D4 & 4.58 & 1000 \\
a5 & 9.92 & D5 & 4.57 & 1000 \\
a6 & 10.38 & D6 & 4.57 & 1000 \\
a7 & 10.22 & D7 & \\
\hline
\end{tabular}




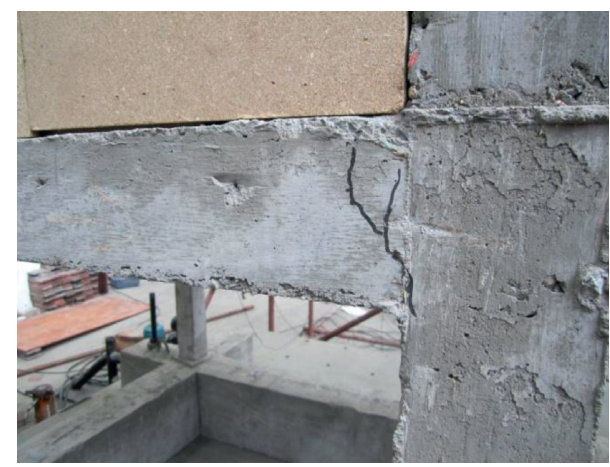

FIGURE 11: Diagonal cracks in a beam of straw frame.

(8) Under $1100 \mathrm{~cm} / \mathrm{s}^{2}$, the bottom columns in the brick frame were twisted, the top of which showed obvious plastic hinge characteristics. The bottom columns in the straw frame twisted in a low amplitude. The local cracks of the brick wall were slightly developed, and the overall performance was good. The straw wall of the top layer of the A axis showed an outward inclining trend. At $1400 \mathrm{~cm} / \mathrm{s}^{2}$, the maximum width of cracks in the bottom column in the brick frame is around $5 \mathrm{~mm}$, as shown in Figure 12. The cracks in the brick walls still developed locally and the walls still presented good integrity. The cracks at the beam ends on the 1st floor of the straw frame are about $3 \mathrm{~mm}$, which all extended to the full sections. The straw wall at the top of axis A was about to crumble. At $1800 \mathrm{~cm} / \mathrm{s}^{2}$, displacement of the top layer in brick frame became too big. As the bottom column broke, the brick frame overturned as a whole, as shown in Figure 13. Straw frame remained intact.

3.3.2. Dynamic Characteristics of Structure. White noise was input on the table before and after the earthquakes at different cases. By performing frequency spectrum analysis on the horizontal acceleration data collected by the acceleration sensor under the action of white noise, the amplitude-frequency curve of the transfer function was acquired. So, the frequencies and damping ratios of the structures were obtained, which are shown in Figures 14 and 15 .

Results show that the attenuation law of the first-order frequency of the two models is basically the same, but the main reasons for the stiffness loss of the testing structures are different. It is also deduced from the damping ratios curve that the straw frame consumes more energy than the brick frame. Apparently, the straw frame with flexible connection has strong energy consumption capacity and is safer than brick frame structure under the action of big earthquakes.

3.3.3. Structural Displacement Response. The maximum interstory displacements and story drifts are shown in Table 7.

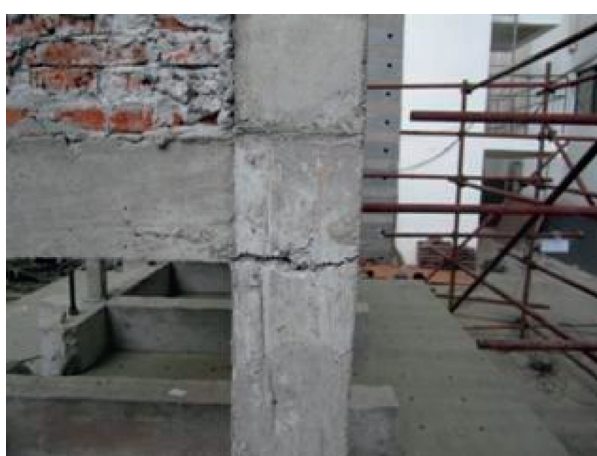

Figure 12: Crack in the bottom column of brick frame.

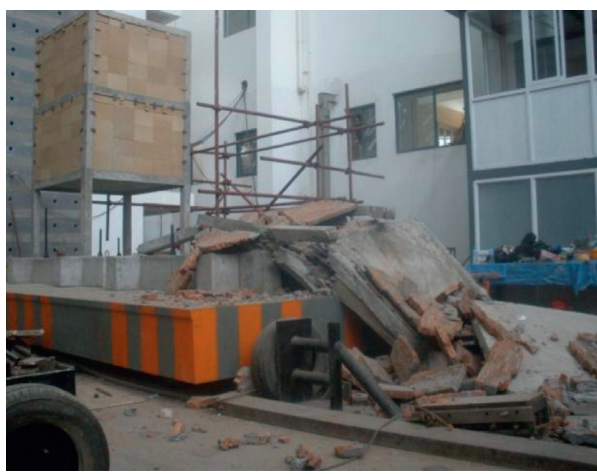

Figure 13: Crumble of the brick frame.

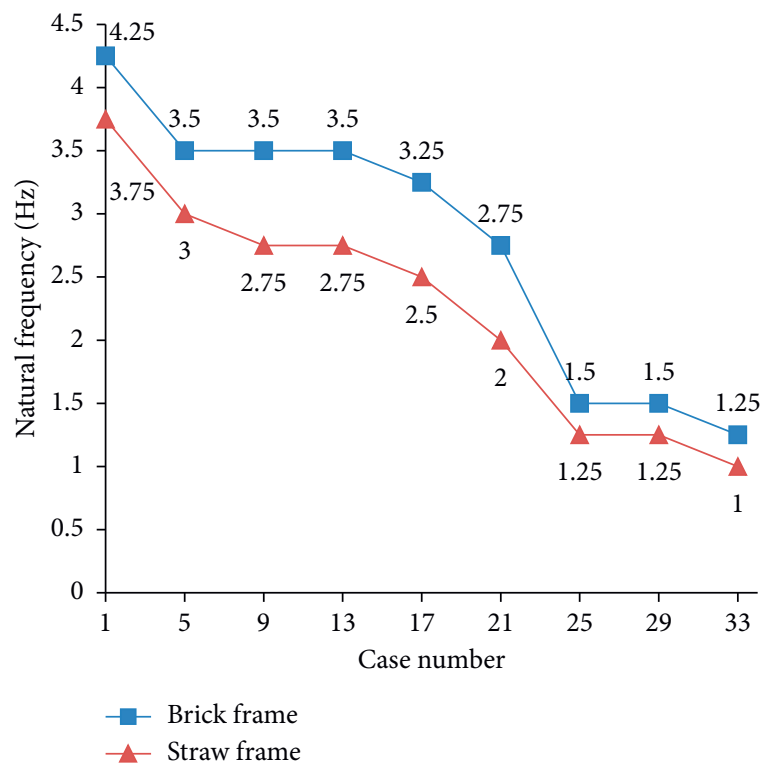

FIgURE 14: The frequencies of models in different cases.

Results show that the max inter story displacements in the brick frame are generally smaller than those of the straw frame under the same lateral actions, due to the extra stiffness the masonry wall brings. It is not difficult to explain why the max story displacements occurred in the first story of the brick wall, while max story displacements appeared in the first and third story of the straw frame. Because masonry 


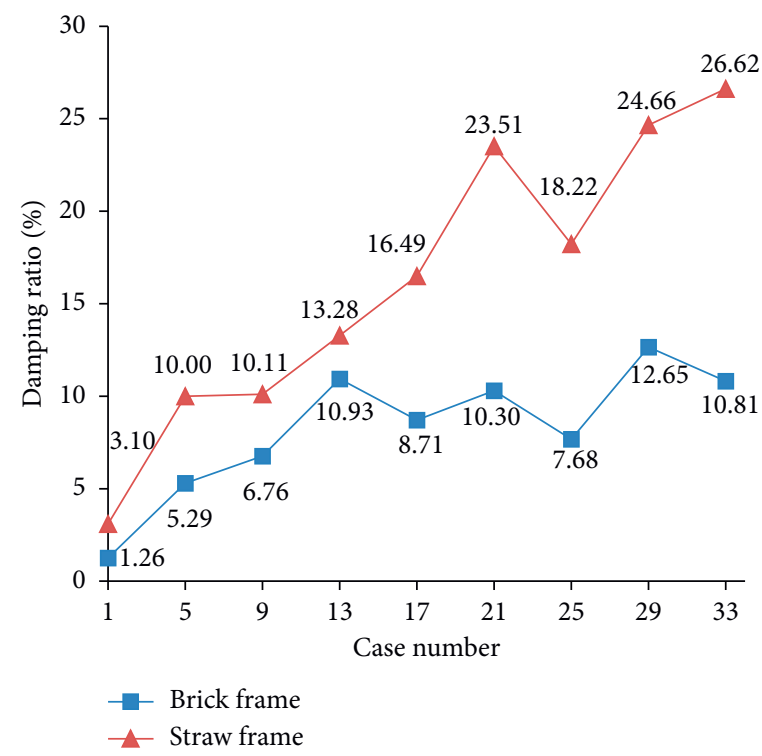

FIgURe 15: Damping ratios of models in different cases.

TABle 7: Maximum interstory displacements and story drifts.

\begin{tabular}{lccccc}
\hline $\begin{array}{l}\text { Peak acceleration } \\
\left(\mathrm{cm} / \mathrm{s}^{2}\right)\end{array}$ & $\begin{array}{c}\text { Brick frame } \\
\text { Max interstory displacement } \\
(\mathrm{mm})\end{array}$ & $\begin{array}{c}\text { Max story } \\
\text { drift }\end{array}$ & $\begin{array}{c}\text { Floor } \\
\text { number }\end{array}$ & $\begin{array}{c}\text { Max interstory displacement } \\
(\mathrm{mm})\end{array}$ & $\begin{array}{c}\text { Max story } \\
\text { drift }\end{array}$ \\
\hline 35 & 0.49 & $1 / 2041$ & 1 & 0.48 & $1 / 2083$ \\
number
\end{tabular}

walls offered extra stiffness, and restricted the deformation of brick frame, this makes the 1st layer much weaker, as no bricks are arranged there. Straw walls, however, brought little extra stiffness to the original structure, hardly affecting the deformation of straw frame.

\section{Numerical Analysis}

The objective of this section is to verify and illustrate the failure mechanism of test structures.

4.1. FEM Models. By using SAP2000 (version 22.1.0), numerical analysis models of frameworks were built based on experimental structures. The only difference of FEM models was the way that those infill walls were considered. Compression struts, with no mass, were adopted to represent the stiffness contribution of masonry walls, as code ASCE/SEI 41-06 [17] proposed. The width of strut was the same with the thickness of masonry infill walls, namely, $40 \mathrm{~mm}$. And the depth of strut was calculated based on (equation (7)) [17], which was $148 \mathrm{~mm}$. With low elastic modulus and flexible connection, however, straw wall was treated as nonstructure component, whose stiffness was ignored. Both the self-weight of masonry bricks and straw panels were considered as vertical linear loads on beams.

To study the failure mechanism, plastic hinges were defined at both ends of all columns and beams. Pushover analysis was conducted, with gradient horizontal loads being imposed on each floor. The FEM models of brick framework and straw framework are shown in Figures 16 and 17. " $H$ " in the figures represents plastic hinge; dimensionless values of the horizontal loads merely illustrate the ratio of acting pushover loads.

4.2. Numerical Results and Discussion. As pushover analysis proceeded, plastic hinges took place. Figures 18 and 19 show records of the pushover steps, where first hinges that reached $C$ stage [16] appeared. In the straw framework, the first failure hinge emerged at the beam end of the 1st floor, while 7 other hinges appeared in other beams and columns. In the brick framework, first failure hinges took place only 


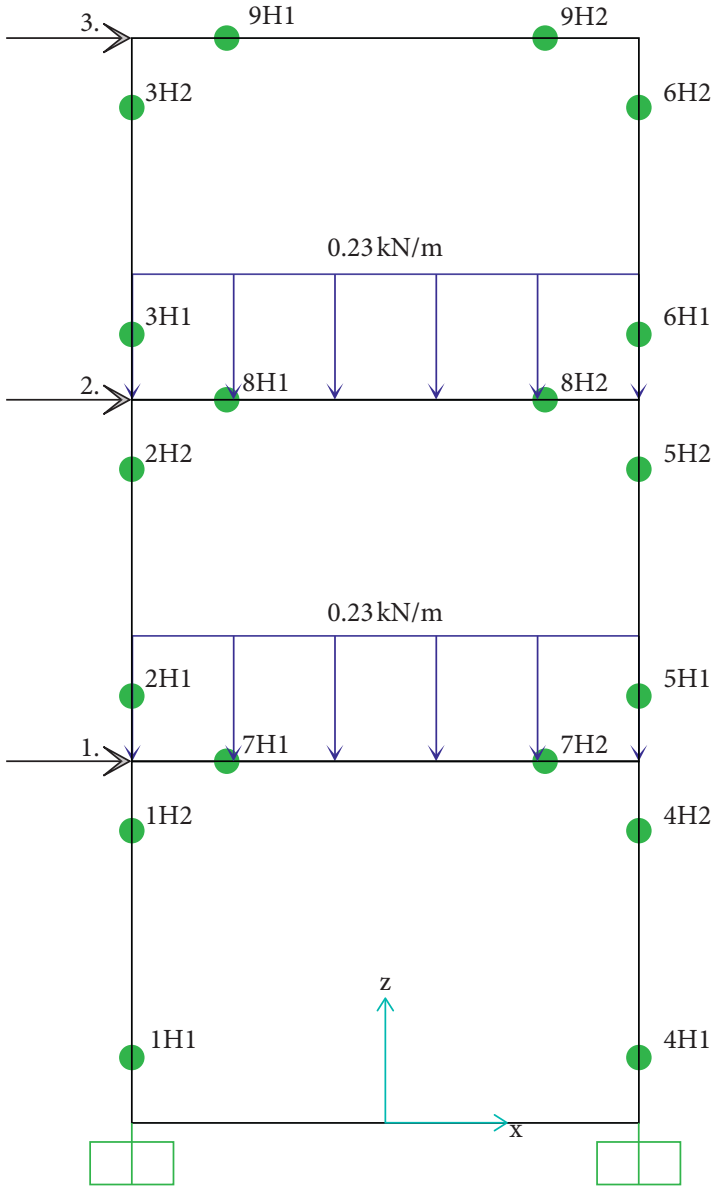

FIGURE 16: FEM model of straw framework.

at the column ends of the 1st floor. Table 8 lists the displacements, story displacements, and story drifts at the time.

Results show that before the failure of structure, the straw frame withstands greater lateral deformation than brick frame does under the same lateral action mode. From bottom to top, the story drifts of brick frame decrease dramatically than those of straw frame, which indicates that the masonry infill walls stupendously enhance the lateral stiffness of upper floors. However, when it comes to the story drifts of first stories, the brick frame apparently owns a bigger value. Above all, masonry infill walls on upper floors result in the localized increase of stiffness, leading to the redistribution of stress generated by lateral actions. This was presented in the form of a weaker first story, eventually a weaker frame than a straw frame or a bare one.

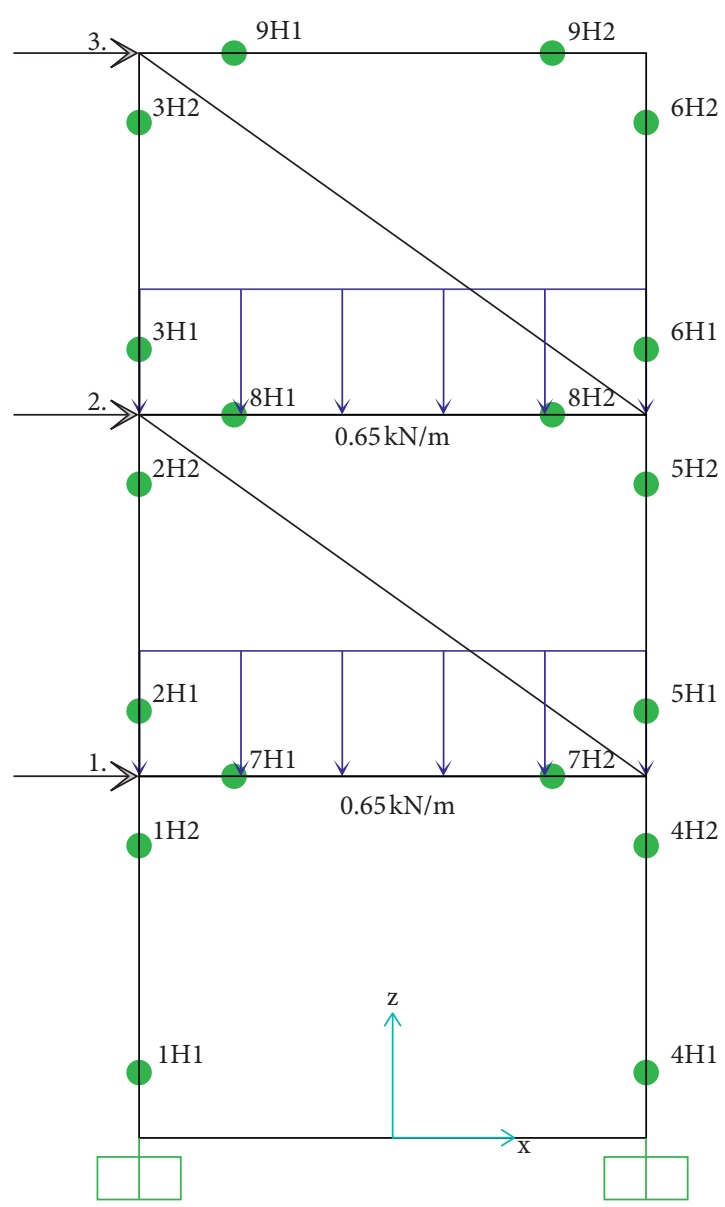

FIGURE 17: FEM model of brick framework.

With the difference of these structures produced by unequal stiffness, the failure modes differ. Numerical analyses show that the first failure hinge took place at the end of the 1st floor beam in the straw frame, while the first failure hinges appeared at the ends of the bottom columns in the brick frame, which accords with the experimental observations above. Failure of beams undoubtedly brings about local damage, while it sometimes in turn protects the structures by absorbing and dissipating part of the seismic energy. However, as vertical load bearing members, the failure of columns would lead to the collapse of the whole structure. This is the reason why the Chinese code [7] recommends the notion of strong column and weak beam, making sure columns fail after beams to protect the living at its best in seldomly occurred earthquakes. In a word, straw frame presents better seismic performance than brick frame. 


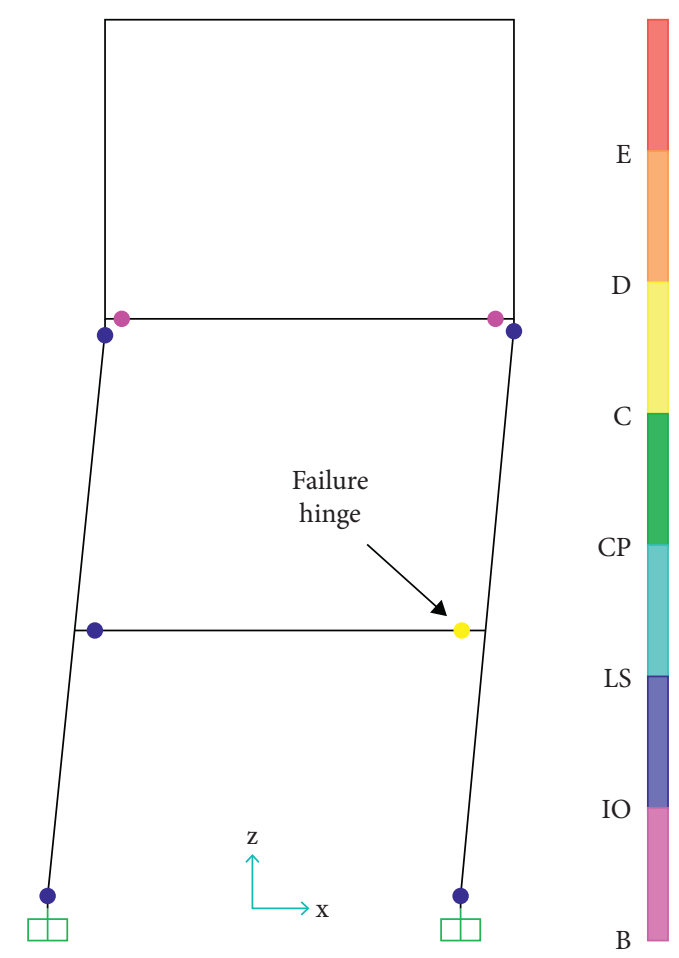

FIgURE 18: Hinges distribution of straw framework.

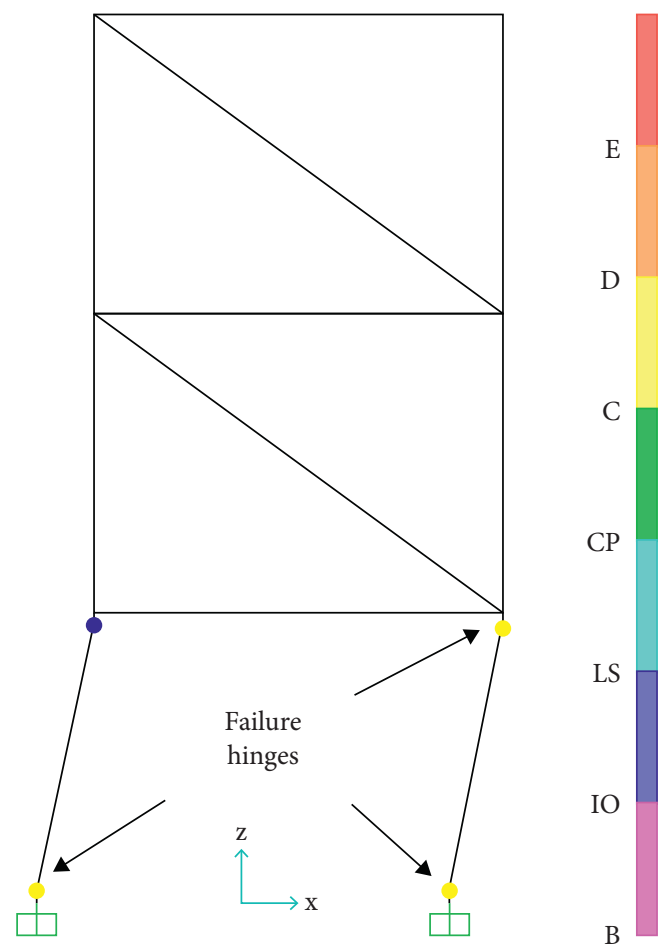

FIgURE 19: Hinges distribution of brick framework.

TABLE 8: Displacements and story drifts of numerical models when the first failure hinges appeared.

\begin{tabular}{lcccccccccc}
\hline \multirow{2}{*}{ Framework } & \multicolumn{3}{c}{ Displacement $(\mathrm{mm})$} & \multicolumn{3}{c}{ Interstory displacement $(\mathrm{mm})$} & \multicolumn{2}{c}{ Story drift } \\
& 1st floor & 2nd floor & 3rd floor & 1st floor & 2nd floor & 3rd floor & 1st floor & 2nd floor & 3rd floor \\
\hline Straw frame & 20.40 & 40.64 & 45.74 & 20.40 & 20.24 & 5.10 & $1 / 49$ & $1 / 50$ & $1 / 196$ \\
Brick frame & 26.03 & 27.06 & 27.49 & 26.03 & 1.03 & 0.43 & $1 / 39$ & $1 / 971$ & $1 / 2326$ \\
\hline
\end{tabular}




\section{Conclusion}

After the shaking table tests are conducted to study the seismic performance of a 1/3-scale straw panel-infilled frame in comparison with masonry infilled frame, along with the numerical analysis, the following conclusions are drawn:

(1) As the story drifts of brick frame are generally smaller than those of straw frame under the same load cases, the masonry walls greatly affect the stiffness of original frame. Consequently, ignoring the stiffness contribution of masonry infill walls in seismic design process is inappropriate and dangerous.

(2) According to the outcome of test results and numerical analysis, inconsistent layout of masonry infill walls along the vertical direction results in the disparity of lateral stiffness for successive stories, leading to the redistribution of stress generated by lateral actions. Eventually, the failure mode shifts to a brittle type, as the stress concentration firstly harms the columns in weak stories.

(3) The proposed straw panels, with lightweight and flexible connections, bring less mass and little extra stiffness to bare frames. Thus, great disparity of lateral stiffness along vertical direction will not be achieved. Consequently, the failure mode is consistent with that of the bare frame, in which the beams damage firstly and consume part of the seismic energy to ensure the whole structure resisting the seismic actions better. The damping ratios' curve also showed that the straw frame consumes more energy than the brick frame. With proper design, the straw panel-infilled frame is a good system combined with safety and flexibility in building space layout.

\section{Data Availability}

The data used to support the findings of this study are available from the corresponding author upon request.

\section{Conflicts of Interest}

The authors declare that they have no conflicts of interest regarding the publication of this paper.

\section{Acknowledgments}

This research was supported by the National Key R\&D Program of China (Grant no. 2017YFC0703507), Basic Ability Improvement Program of Young- and Middle-Aged Scholar for the Education Office of Guangxi Zhuang Autonomous Region (Grant no. 2019KY0256), and Priority Academic Program Development of Jiangsu Higher Education Institutions (PAPD).

\section{References}

[1] I. Koutromanos, "Numerical modeling of masonry-infilled RC frames subjected to seismic loads," Computers \& Structures, vol. 89, no. 11-12, pp. 1026-1037, 2011.
[2] F. De Luca, G. M. Verderame, F. Gómez-Martínez, and A. Pérez-García, "The structural role played by masonry infills on RC building performances after the 2011 Lorca, Spain, earthquake," Bulletin of Earthquake Engineering, vol. 12, no. 5, pp. 1999-2026, 2014.

[3] G. Blasi, D. Perrone, and M. A. Aiello, "Fragility functions and floor spectra of RC masonry infilled frames: influence of mechanical properties of masonry infills," Bulletin of Earthquake Engineering, vol. 16, no. 12, pp. 6105-6130, 2018.

[4] F. Braga, V. Manfredi, A. Masi, A. Salvatori, and M. Vona, "Performance of non-structural elements in RC buildings during the L'Aquila, 2009 earthquake," Bulletin of Earthquake Engineering, vol. 9, no. 1, pp. 307-324, 2011.

[5] P. G. Asteris, C. C. Repapis, E. V. Repapi, and L. Cavaleri, "Fundamental period of infilled reinforced concrete frame structures," Structure and Infrastructure Engineering, vol. 13, no. 7, pp. 929-941, 2017.

[6] Press CCI, Technical Specification for Concrete Structures of Tall Building (JGJ3-2010), The Ministry of Housing and Urban-Rural Development of the People's Republic of China, Beijing, China, 2011.

[7] Press CCI, Code for Seismic Design of Buildings (GB500112010), The Ministry of Housing and Urban-Rural Development of the People's Republic of China, Beijing, China, 2016.

[8] Research, C. A. O. B., Photo Collection of 2008 Wenchuan Earthquake Damage to Buildings, China Construction Industry Press, Beijing, China, 2008.

[9] Z. Z.-Q. Huang Dong-Sheng, "MAO long-quan investigations of building damages in mianzhu and dujiangyan due to 5.12 wenchuan earthquake," Journal of Disaster Prevention and Mitigation Engineering, vol. 30, no. 01, pp. 109-116, 2010.

[10] A. Stavridis, I. Koutromanos, and P. B. Shing, "Shake-table tests of a three-story reinforced concrete frame with masonry infill walls," Earthquake Engineering \& Structural Dynamics, vol. 41, no. 6, pp. 1089-1108, 2012.

[11] M. Shabdin, N. K. A. Attari, and M. Zargaran, "Shaking table study on the seismic performance of an Iranian traditional Un-Reinforced Masonry (URM) building," Structures, vol. 27, pp. 424-439, 2020.

[12] H. Wijaya, "Effect of infill-wall material types and modeling techniques on the seismic response of reinforced concrete buildings," Natural Hazards Review, vol. 21, no. 3, 2020.

[13] M. H. Santhi, G. M. S. Knight, and K. Muthumani, "Evaluation of seismic response of soft-storey infilled frames," Computers and Concrete, vol. 2, no. 6, pp. 423-437, 2005.

[14] T. Suzuki, H. Choi, Y. Sanada et al., "Experimental evaluation of the in-plane behaviour of masonry wall infilled RC frames," Bulletin of Earthquake Engineering, vol. 15, no. 10, pp. 4245-4267, 2017.

[15] T. Salonikios, C. Karakostas, V. Lekidis, and A. Anthoine, "Comparative inelastic pushover analysis of masonry frames," Engineering Structures, vol. 25, no. 12, pp. 1515-1523, 2003.

[16] FEMA-440, Improvement Of Nonlinear Static Seismic Analysis Procedures, Applied Technology Council (ATC), Washington DC, USA, 2005.

[17] (ASCE), A. S. O. C. E., Seismic Rehabilitation of Existing Structures (41-06), ASCE, Reston, VA, USA, 2007.

[18] P. G. Asteris, D. M. Cotsovos, C. Z. Chrysostomou, A. Mohebkhah, and G. K. Al-Chaar, "Mathematical micromodeling of infilled frames: state of the art," Engineering Structures, vol. 56, pp. 1905-1921, 2013.

[19] Z. Xu, Z. Chen, and S. Yang, "Seismic behavior of cold-formed steel high-strength foamed concrete shear walls with straw boards," Thin-Walled Structures, vol. 124, pp. 350-365, 2018. 
[20] L. Jian, The Experimental Investigation of the Straw Bale Wall under the Horizontal Loads, Jilin Jianzhu University, Changchun, China, 2015.

[21] A. D. González, "Energy and carbon embodied in straw and clay wall blocks produced locally in the Andean Patagonia," Energy and Buildings, vol. 70, pp. 15-22, 2014.

[22] K. Li, "Analysis on energy saving and thermal insulation performance of improved straw brick in northern cold area," Arabian Journal of Geosciences, vol. 13, no. 16, 2020.

[23] D. Snoeck and N. De Belie, "From straw in bricks to modern use of microfibers in cementitious composites for improved autogenous healing - a review," Construction and Building Materials, vol. 95, pp. 774-787, 2015.

[24] F. Parisi, D. Asprone, L. Fenu, and A. Prota, "Experimental characterization of Italian composite adobe bricks reinforced with straw fibers," Composite Structures, vol. 122, pp. 300-307, 2015.

[25] F. S. Liu, J. Fan, and H. B. Bian, "A new cost effective building material: compacted wheat straw block," Advanced Materials Research, vol. 374-377, pp. 2599-2604, 2011.

[26] C. C. I. Press, Code for Design of Concrete Structures (GB50010-2010), The Ministry of Housing and Urban-Rural Development of the People's Republic of China, Beijing, China, 2015.

[27] C. C. I. Press, Code for Design of Masnory structures (GB50003-2011), The Ministry of Housing and Urban-Rural Development of the People's Republic of China, Beijing, China, 2011. 